\title{
Managing Healthcare for an Aging Population: Are Demographics a Fiscal Iceberg for Newfoundland and Labrador?
}

\author{
by
}

Colin Busby, William B.P. Robson and Aaron Jacobs

\begin{abstract}
"The growth in health care spending can be attributed to a number of factors, including the aging of our population, geographical layout of the province, new and more expensive treatments, increased incidence of chronic disease and increased health provider costs... Although complex, this creates an opportunity where through a renewed focus on collaboration, innovation and best practices, health and community services will become more efficient and quality of care enhanced." (Newfoundland and Labrador 2013-14 Annual Performance Report - Department of Health and Community Services, p. 47.)
\end{abstract}

For years, a debate has raged over the fiscal impact of demographic change - in particular, whether providing publicly funded healthcare to an aging population will financially stress Canadian governments. One camp, developing a theme that the pressures resemble a glacier more than an avalanche, has emphasized that aging itself adds no more than one percentage point to annual increases in health costs. Therefore, it argues there is no urgency around reforms to treatment or financing (Barer et al. 1995; Evans et al. 2001). If taxes are allowed to rise and provider compensation can be curbed, so goes the argument, the system is as sustainable as Canadians want it to be.

The other camp has emphasized that a one-percentage-point annual increase is substantial, especially when it compounds over many years. Moreover, aging will slow the growth of the tax base, potentially compromising healthcare as well as other major government programs, tax rates

This E-Brief is part of a provincial series profiling the fiscal challenge of aging and publicly funded healthcare in each province. It updates a previous series in 2013. We gratefully acknowledge the support of Alexandre Laurin in calculating program costs and thank members of the C.D. Howe Institute's Health Policy Council for comments on earlier drafts. However, we alone are responsible for any errors and the conclusions. 
and debt control (Robson 2001, 2007, 2010; Drummond and Burleton 2010; Dodge and Dion 2011; and Emery et al. 2012). This camp might concede that glaciers move slowly. Like icebergs, however - to choose an image more apt for Newfoundland and Labrador - their slow movement belies their formidable impact when they arrive. So this camp tends to urge major reforms to healthcare delivery and financing to mitigate an otherwise painful looming collision between demographically sensitive programs and other fiscal priorities.

At first glance, this debate might seem unimportant to Newfoundland and Labrador, a province where publicly funded healthcare's claim on resources has not shown the same upward trend evident elsewhere in Canada. As a share of provincial GDP, healthcare has fallen from 9 percent in 1991 to about 7.4 percent in 2014. While it has risen from 30 percent of the provincial program spending in 1991 to about 39 percent in 2014, its share of provincial own-source revenue - that is, revenues Newfoundland and Labrador raises itself rather than funds transferred from Ottawa - has fallen from 51 percent in 1991 to about 44 percent.

The above quotation from the 2014 Report, however, highlights demography as one key pressure on health spending and acknowledges the need for innovative changes. Do these pressures create a fiscal iceberg for the province?

\section{Mapping Today's Spending onto Tomorrow's Population}

We address that question with a well-known, straightforward approach. We project Newfoundland and Labrador's population growth using the following middle-of-the-road assumptions: a fertility rate stable at the 2011 provincial level; longevity rising in line with Statistics Canada's "medium" improvement scenario; net outmigration to other provinces falling to zero over 10 years and net international in-migration continuing at a rate equivalent to its 1991-to-2013 average.

We then multiply the potential workforce, which we define as the province's population age 18 to 64 , by an index of output per potential worker. This index increases by 1.2 percent annually, the rate recorded by the equivalent national measure from 1991 to 2013. These calculations provide our model with projections of real provincial gross domestic product (GDP), which we convert to nominal dollars. (Nominal provincial GDP is real GDP multiplied by the same 2 percent inflation rate we assume will prevail nationally.)

The impact of aging on future workforce growth and GDP often gets little attention in the healthcare spending debate. But they are set to grow much more slowly than they have over the past few decades (Figure 1). Hence, the province's tax base will grow more slowly than in prior years and will reduce the ability of provincial finances to accommodate growth in healthcare costs.

Turning to the cost pressures on healthcare, we project expenditure for each sex in 20 age groups across six types of spending. Per-person expenditure for each of these groups grows according to a measure of volume of services delivered and a cost index. The volume measure - an index of service intensity - represents spending on all services provided per person by the publicly funded healthcare system, adjusted to remove the effects of inflation. Our base figures for these per-person numbers are the Canadian Institute of Health Information (CIHI) figures for 2012, pro-rated to match recent actual totals. ${ }^{1}$

1 For our projections, we use CIHI data for spending by age group from 2010-2012 to compute the three-year average share of the total spending for each group. We then use CIHI's 2013 and 2014 spending forecasts and Statistics Canada's population data to compute per capita costs by age group, assuming the relative spending on each group will be similar. 


\section{Figure 1: Annual Growth in Newfoundland and Labrador's Labour Force and GDP,} 1982-2064

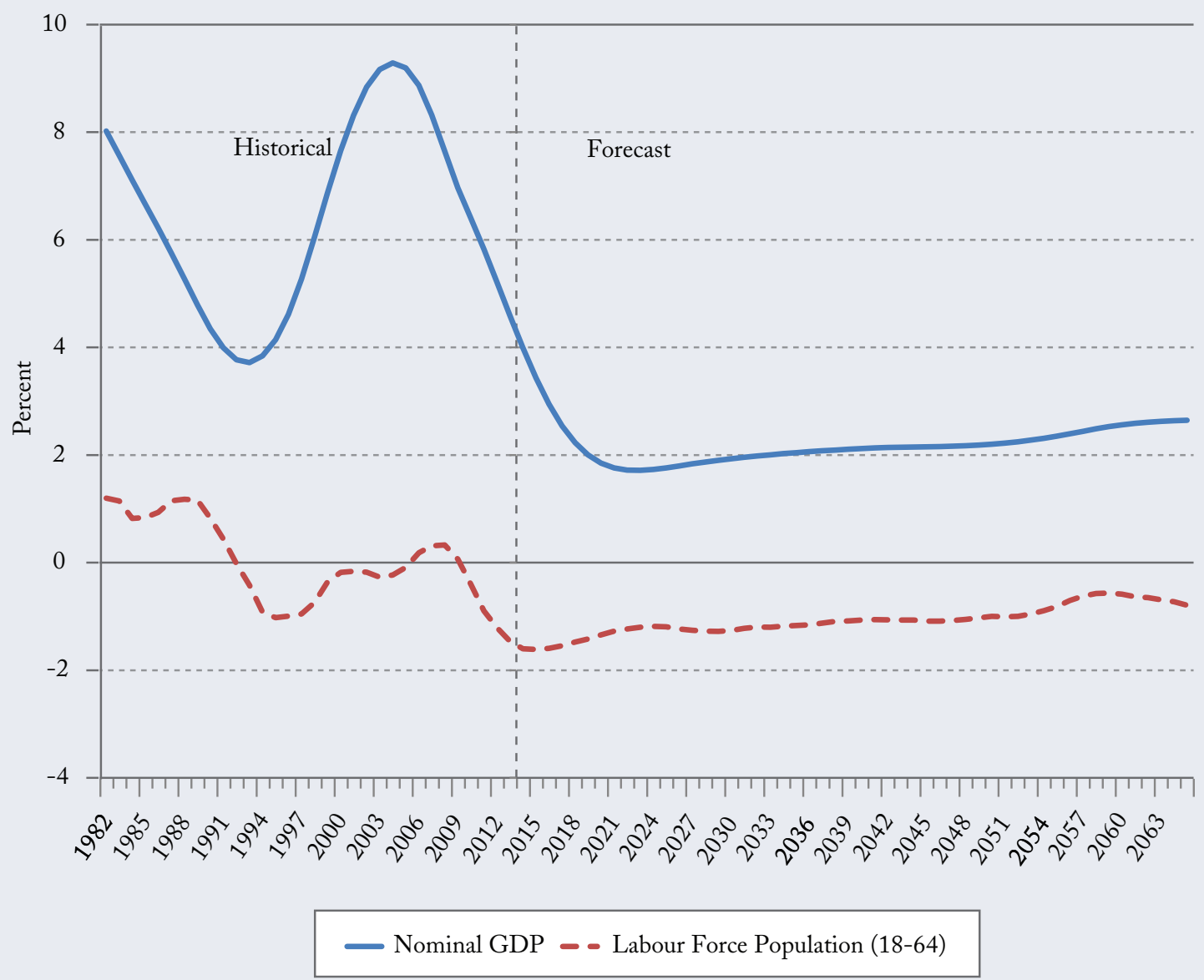

Note: GDP and Labour Force Population data have been smoothed to reduce the effects of short-term fluctuations in the historical data.

Source: Authors' calculations as described in text.

Looking forward, we assume that service intensity per person will rise at the same rate as real output per potential worker - 1.2 percent annually. In terms of cost increases, the government consumption price index nationwide from 1991 to 2012 recorded annual growth at 2.5 percent annually - 0.5 of a percentage point above overall inflation. The last few years have seen a decline in health-cost inflation, along with lower increase in overall health spending. We hesitate to project more recent moderate rates indefinitely, recalling the $1990 \mathrm{~s}$ when a period of restraint was followed by resumed rapid growth. So we project healthcare cost inflation at 1.3 percent through 2020, followed by a slow return the historical margin over economy-wide inflation.

Because demography also affects other programs, we use similar methods - indexes of service intensity in the case of education and indexes of transfers for elderly and child/family benefits - multiplied by relevant populations and price indexes to project future spending in these areas (Box 1 spells out our approaches for 
health and these other programs in more detail). In this way, we can see whether these programs offset, or exacerbate, any fiscal challenge presented by healthcare.

\section{Newfoundland and Labrador's Outlook: Trends and Implicit Liability}

Our projections show Newfoundland and Labrador's spending rising from 7.4 percent of provincial GDP this year to 13.1 percent in 2035 and to 17.7 percent in 2064. Taking account of other demographically sensitive programs does not change the prospect of fiscal stress. In Newfoundland and Labrador, spending on senior and family programs is small, and the implicit liability from the former and the implicit asset from the other are not material.

Rising service intensity in education more than offsets a relative decline in the population of students. The net result is the GDP share of all these programs more than doubles, from 11.8 to 23.5 percent, over the 50-year period (Figure 2). For Newfoundland and Labrador to meet these demands from its own revenue sources would require an increase of some 60 percent in the provincial tax bite.

Most public discussion of healthcare and other programs emphasizes maintaining them - perhaps enhancing, but certainly not cutting. And the Newfoundland and Labrador government is certainly not promising higher tax rates. These political understandings create an implicit liability on the government's balance sheet, because meeting these commitments will require the government to tax a higher share of provincial income. ${ }^{2}$

One way to quantify the looming healthcare funding liability is to calculate the present value of changes in these programs' claims on GDP over the next half-century. Discounting the cumulative increase in the province's average tax take from its current level by the yield on provincial long-term bonds, ${ }^{3}$ the province's implicit liability amounts to $\$ 73$ billion, nearly 90 percent of which ( $\$ 65$ billion) relates to healthcare (see Table 1$).{ }^{4}$ In other words, to cover the additional 50-year cost of these programs, the province would need more than $\$ 70$ billion in assets yielding returns at the same rate as its long-term bonds. This is a huge amount - an iceberg indeed more than double provincial GDP, or some $\$ 140,000$ per Newfoundlander and Labradorian.

\section{Policy Pressures and Responses}

The debate over aging's impact on healthcare rages intensely partly because, implicitly and often explicitly, the two camps differ over the size and scope of needed changes to healthcare funding and delivery. Our analysis

2 The parallel with explicit liabilities is straightforward: if Newfoundland and Labrador decides to cover the higher program costs by borrowing rather than raising its aggregate tax rate, the implicit liability would, over time, become higher public debt.

3 We use a nominal discount rate of 3.5 percent to discount future nominal costs.

4 As we explain in Box 1, the labour intensiveness of healthcare (and education) services provides some justification for linking service intensity to economy-wide productivity. The assumption that both grow together is clearly critical to our results. Should Newfoundland and Labrador manage to constrain growth in service intensity to 0.5 percentage point less than growth in productivity -0.7 percent annually, rather than the 1.2 percent we assume in our projections - demographically sensitive spending would be 20.3 percent of GDP in 2064 and the unfunded liability today would be $\$ 65$ billion. Historically, service intensity has tended to outpace productivity: if it grew 0.5 percentage point faster - 1.7 percent annually - demographically sensitive spending would be 29.9 percent of GDP in 2064 and the unfunded liability would be $\$ 108$ billion. 


\section{Box 1: Projecting Other Demographically Sensitive Program Costs}

We use similar projection methods - multiplying relevant populations by program-specific indexes of service or transfer intensity - for all the programs we examine."

We assume that service intensity - the volume of services delivered per person in healthcare and education - rises at the same rate that output per person in the economy as a whole does. This assumption is not entirely arbitrary: absent good quantitative measures of quality of output, measures of activity in unpriced services such as health and education tend to be driven by inputs. These are labour-intensive activities: wages - which tend to rise with economy-wide productivity - are a key input. Historically, service intensity has grown at annual rates above the 1.2 percent we assume, and faster than productivity growth. We prefer to link them in our main projection in order to ensure that trends upward or downward in the shares of health and education spending in GDP are not a function of different assumptions about service intensity on the one hand, and productivity growth on the other, but rather products of demographic change and cost inflation in government consumption compared to inflation elsewhere.

Our index of transfer intensity for seniors' benefits is derived from the Office of the Chief Actuary's projections of spending on Old Age Security, the Guaranteed Income Supplement, and Allowances. Because many of those programs are geared to income, and the Chief Actuary's model assumes that incomes rise over time, this index tends to fall somewhat in real terms.. Our index of transfer intensity for child and family benefits does not change over time: we assume that the real value of transfers per person in the relevant age group is constant.

Further notes on the projections for programs other than health follow:

Education: Base-year provincial/local spending on elementary and secondary education is calculated using data from Statistics Canada's Summary of Public School Indicators for the Provinces and Territories, 2005/06 to 2009/10.). Base-year spending on postsecondary education comes from Statistics Canada (CANSIM, table 3850001). Provincial populations aged 4 to 17 and 18 to 24 drive provincial spending on elementary and secondary students respectively. We multiply these populations by our indexes of service intensity. The population under 17 drives the federal Canada Education Saving Grant, while the population aged 18 to 24 and service intensity drive federal grants to postsecondary students. We multiply these by an unchanging index of transfer intensity.

Elderly benefits: Base-year federal spending is from the public accounts; base-year provincial spending is from Statistics Canada's Social Policy Simulation Database and Model (SPSD/M), Release 21.0 (responsibility for use and interpretation rests with the authors). As just noted, provincial payments assume the same time-path of service or transfer intensity for provincial elderly populations.

Child/family benefits: Spending on the federal Universal Child Care Benefit varies with the national population of children to age 5; spending on other child-related benefits varies with relevant populations up to age 17 . We assume unchanging indexes of transfer intensity. Federal family benefits delivered through the tax system, while indexed to inflation, are income-tested, so real income growth erodes their real value. SPSD/M simulations suggest that in the scenarios modeled here, these offsetting characteristics leave average nominal spending per child unchanged - an assumption that has also been made for (generally much smaller) provincial programs.

* For more background on the methodology used and the terminology see Robson (2002) and Drummond and Burleton (2010). 
Figure 2: Newfoundland and Labrador's Demographically Sensitive Programs as a Share of GDP, 2014-2064

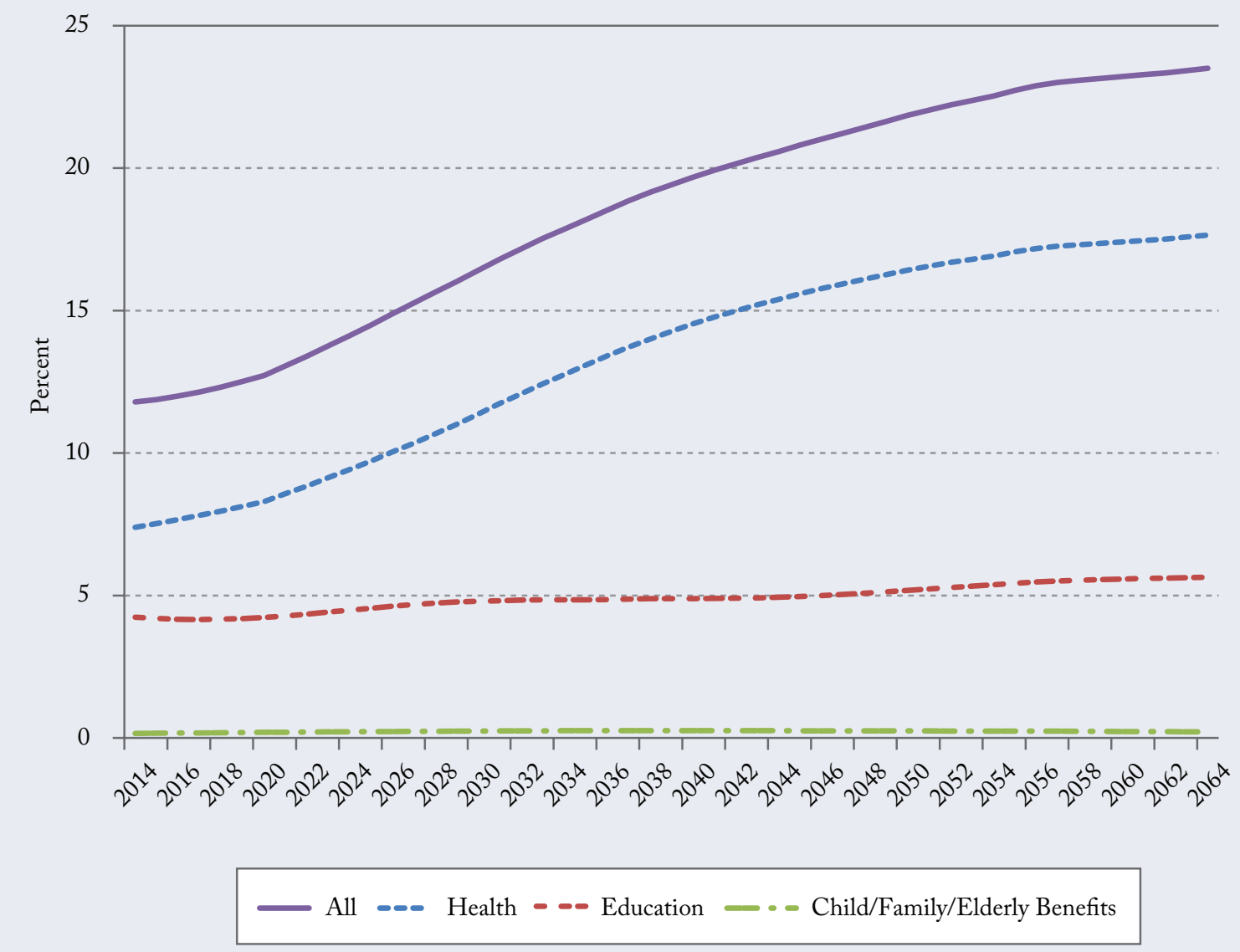

Source: Authors' calculations as described in text.

suggests that, notwithstanding the relative ease with which the province has financed its healthcare system over the past few years, pressure for reform will intensify in the future.

\section{The False Hope of a Federal Bailout}

A regular theme in discussions of fiscal pressures affecting Canada's provinces is the role the federal government could - and, especially when the conversation is with premiers and other provincial officials, should - play in helping them out. Since any increases in net federal transfers to Newfoundland and Labrador would have to come at the expense of other provinces, it is hard to see such increases being economically or politically attractive. The pressure of healthcare spending on other programs and taxes is a problem Newfoundland and Labrador should tackle on its own.

What proactive moves by the province make sense to improve the chances of achieving other fiscal goals while preserving and enhancing the quality of the province's healthcare system? 


\section{Table 1: Newfoundland and Labrador's Implicit Liabilities in a National Context}

Demographically Sensitive Programs

\begin{tabular}{|c|c|c|c|c|c|c|c|}
\hline Region & Health & Education & $\begin{array}{l}\text { Elderly } \\
\text { Benefits }\end{array}$ & $\begin{array}{l}\text { Child/ } \\
\text { Family } \\
\text { Benefits }\end{array}$ & $\underset{\text { Programs }}{\text { All }}$ & $\begin{array}{c}\text { All } \\
\text { Programs } \\
\text { Relative } \\
\text { to GDP } \\
(2014)\end{array}$ & $\begin{array}{c}\text { All } \\
\text { Programs } \\
\text { per } \\
\text { Person }\end{array}$ \\
\hline & \multicolumn{5}{|c|}{$\$$ Billions } & Percent & $\$$ \\
\hline $\mathrm{BC}$ & 383.6 & 18.3 & 0.7 & -1.2 & 401.4 & 171 & 87,029 \\
\hline $\mathrm{AB}$ & 580.1 & 108.3 & 16.5 & -0.6 & 704.3 & 204 & 171,999 \\
\hline SK & 79.3 & 30.5 & 0.5 & - & 110.3 & 130 & 99,069 \\
\hline $\mathrm{MB}$ & 90.6 & 27.4 & 0.0 & 0.0 & 118.0 & 189 & 92,775 \\
\hline $\mathrm{ON}$ & $1,194.2$ & 194.0 & 1.5 & -6.4 & $1,383.3$ & 195 & 101,265 \\
\hline QC & 681.9 & 139.6 & - & -14.7 & 806.8 & 218 & 98,373 \\
\hline NB & 67.7 & 8.3 & 0.0 & 0.0 & 76.0 & 233 & 100,678 \\
\hline NS & 89.1 & 9.3 & - & 0.0 & 98.4 & 247 & 104,814 \\
\hline $\mathrm{PE}$ & 13.0 & 2.5 & - & - & 15.5 & 263 & 106,538 \\
\hline NL & 65.1 & 7.4 & 0.0 & 0.9 & 73.4 & 201 & 140,209 \\
\hline YT & 9.0 & 1.0 & - & - & 10.0 & 387 & 274,687 \\
\hline NWT & 13.9 & 2.8 & - & - & 16.7 & 370 & 380,070 \\
\hline NU & 13.9 & 3.1 & - & - & 17.0 & 681 & 464,111 \\
\hline Provincial & $3,244.6$ & 545.6 & 19.2 & -22.0 & $3,787.4$ & 196 & 106,886 \\
\hline Federal & 0.0 & -12.1 & 461.0 & -21.1 & 427.8 & 22 & 12,100 \\
\hline Canada & $3,281.4$ & 540.4 & 480.2 & -43.1 & $4,258.9$ & 298 & 164,700 \\
\hline
\end{tabular}




\section{The Case for Prefunding}

One way to mitigate the impact of rising costs in some healthcare services would be to follow the lead of the late-1990s reforms to the Canada and Quebec Pension Plans, which converted from pay-as-you-go to plans in which a portion of premiums collected from people today prefunded their future needs. Some drug programs, and potentially long-term care as well, are like social security programs in that many people can prepare for predictable expenses by building a provident fund during their younger years.

Like other provinces, Newfoundland and Labrador could selectively convert pay-as-you-go programs so that the babyboomers, rather than depend on their declining number of children and grandchildren, pay some of the higher costs that loom (Robson 2002; Stabile and Greenblatt 2010). Prefunding does not make sense for all the programs with threatened cost increases, but can spread more fairly over time the needed tax increases necessary for health services that, like pensions, are related to age. ${ }^{5}$

\section{Reducing Healthcare Spending's Sensitivity to Aging}

Unlike pensions, which are promises to pay dollars, healthcare promises services, the cost and quality of which are not fixed. The camp that says aging by itself is not a major problem has tended to emphasize that some factors that make per-capita healthcare spending so strongly associated with age, such as high rates of hospitalization or use of certain drugs, may change over time (Evans et al. 2001). To the degree that healthcare spending is related to the end of life, the tendency of people to live longer, healthier lives could mean that future Newfoundlanders' will incur inevitable higher healthcare costs at a later age than today's, which would delay the demographic effects in our model. ${ }^{6}$

Clearly, this is not a simple subject. As Felder (2013) points out, decisions to spend are at least partly driven by the life expectancy of the patient, so it is possible that a population that is living longer, healthier lives might encourage more spending on the "young elderly." Given the difficulty of making firm judgments in this area, we are driven to look at what has actually happened to the age profile of provincial healthcare spending in Newfoundland and Labrador since CIHI's first data in 1998. A comparison of the age profile of spending in 1998 with 2012 (Figure 3) shows that the province's healthcare spending became less strongly geared to age over the period. A 1998 projection of the impact of demography on Newfoundland and Labrador's healthcare spending by 2012 would have overestimated somewhat the impact of aging. That is the good news. The bad news is that in the context of a relatively fast-growing provincial healthcare budget the changes in the spending age profile might be more related to increased spending on other age groups rather than more efficient care for the elderly. We underline that our projections for the future assume that this less age-sensitive spending profile will persist in a more frugal future.

One aspect of Newfoundland and Labrador's healthcare bundle is particularly sensitive to the pressures of aging on costs - long-term care for the elderly. Well over one-half of the population will need continuing care

5 Busby and Robson (2010) explore some prefunding possibilities and their mechanics in more detail.

6 One objection to projecting healthcare costs on the basis of current age-specific service use is that the higher costs associated with older people reflect their higher mortality rates. In other words, these projections overstate future cost increases when people are living longer before they incur those mortality-related costs. As Brown and Suresh (2004) demonstrate, however, projections that distinguish spending on people who survive longer from spending on people who die at various ages produce cost estimates that are only marginally lower than estimates that make no such distinction. 


\section{Figure 3: Average Per Capita Health Spending by Age Group in Newfoundland and}

\section{Labrador, 1998 and 2012}

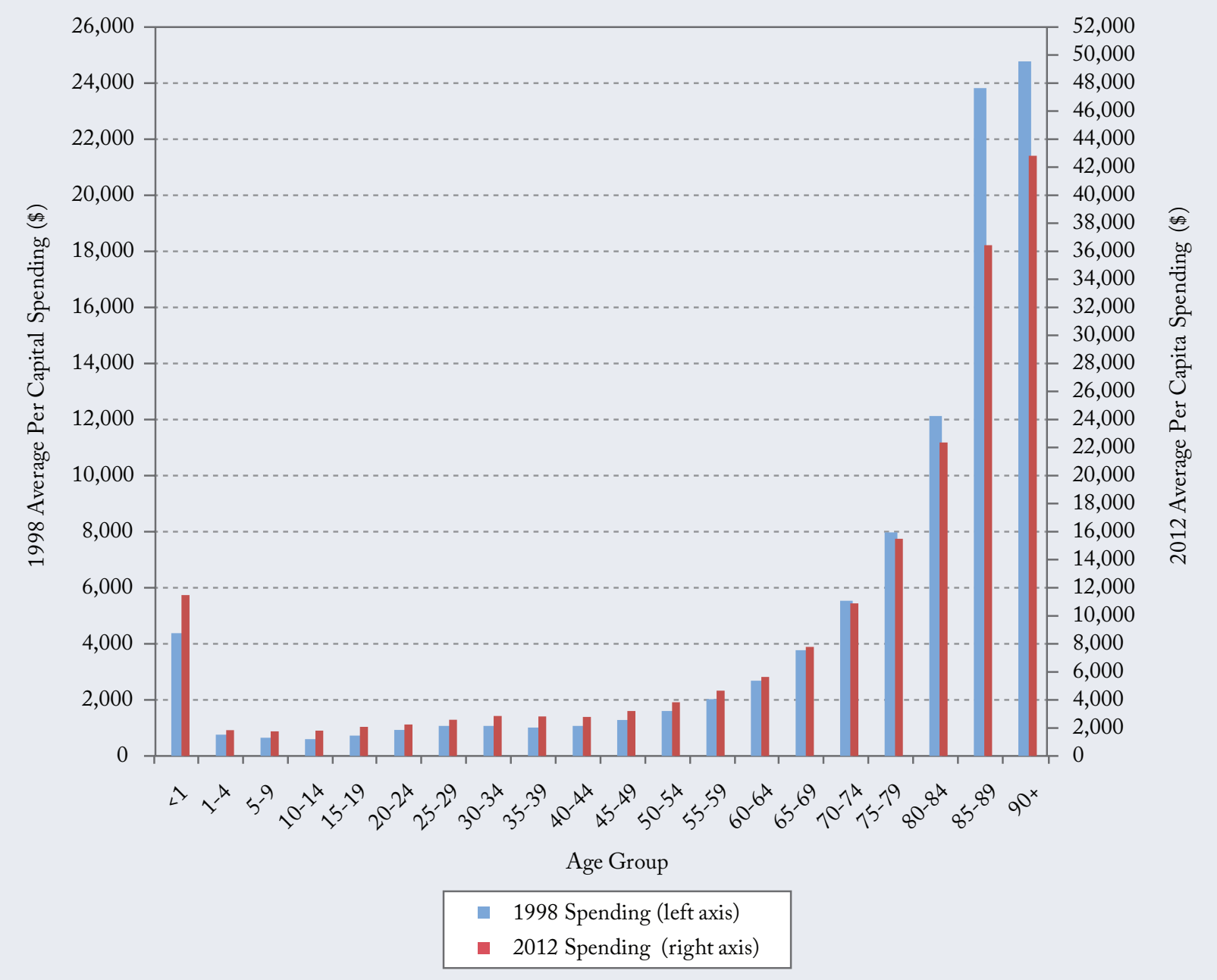

Note: The vertical axes show nominal dollars for transparency's sake: these are the actual dollar figures from CIHI. We could have used constant dollars from either - or, indeed, any year - or index numbers, because this focus of this figure is the relative distribution of health spending by age in the two years. To facilitate comparison of the age-profiles of spending: we have set the vertical scales so roughly half the bars in each year are taller (or shorter) than their counterparts in the other. Source: CIHI (2014).

support at one point in their lives - a proportion that jumps to almost three-quarters after age 65. But many citizens mistakenly believe that governments are going to cover most of their future long-term care costs. This is because public subsidies to long-term care in institutions or at home are generally opaque and misunderstood. The ambiguity of current public-private responsibilities for financing long-term care dampens private savings and pressures the public sphere to pick up the slack.

But an expanded public role here would heighten intergenerational equity concerns, which is why provincial authorities must clearly define the extent to which they will cover future costs. To reduce the connection between 
public health spending and aging, public subsidies for long-term care must be targeted to those without the means to pay for it. At the same time, the government should require that those who can afford it to absorb a meaningful share of the costs. Doing so means setting, and publicizing, government subsidies clearly so that private options - increased savings and insurance - grow to complement public subsidies (Blomqvist and Busby 2014).

\section{Accessible Reforms and Benchmarking Best Practices}

How might Newfoundland and Labrador get more bang for its healthcare buck generally, while insulating its budget from potentially deleterious effects of population aging? Among the areas that experts have identified as promising are:

- more coordinated team-based primary care that gives patients comprehensive non-acute services through an organized group of practitioners from different specialties;

- better coordinated care for patients after they leave hospitals;

- electronic health records;

- scope-of-practice changes to substitute less expensive services of comparable quality from different providers - as, for example, when nurse practitioners perform functions traditionally performed by more expensive physicians;

- more use of clinical evidence to reduce variation in diagnostics and therapeutics use; and

- incentives for patients to take greater responsibility for maintaining their own health.

As well, Canada's provinces exhibit large differences in spending by category and in increases by category over time, that may yield further insights (Table 2 and Table 3). Newfoundland and Labrador spends less per capita than most provinces on "other professionals," which includes dental, vision, chiropractic and other therapist costs. But the province spends more on hospitals and "other institutions," which includes expenditures for nursing homes and residential care facilities, and its overall per capita spending is the highest in the country.

These differences are large. If Newfoundland and Labrador brought its hospital costs in line with the national average, it would save some $\$ 380$ million annually. The quality side of these differences is clearly critical to deciding among priorities - whether to reallocate spending within the healthcare budget or between healthcare and other fiscal priorities - but we do not currently have good knowledge on which to base such decisions. Newfoundland and Labrador has increased per capita healthcare spending for faster than any other province since the early 1990s, and its growth rates in most categories are typically at the top. Has service quality in each category improved apace? Again, we do not know. More inter-provincial benchmarking should help Newfoundland and Labrador, and all provinces, do a better job over time.

\section{Closing Comments}

Because it is set to age faster than most provinces, Newfoundland and Labrador should be concerned about the impact of demographic change on its fiscal situation. The province has had a good run. Now, however, it faces an implicit liability related to demographically sensitive programs that is larger than provincial GDP and raises the prospect of the province doubling the share of provincial income it collects as taxes. In the face of this fiscal iceberg, selective prefunding and benchmarking against other provinces' best practices can help Newfoundland and Labrador deliver high-quality healthcare in a sustainable fiscal framework for years to come. 
Table 2: Real Per Capita Health Spending, by Use of Funds, Newfoundland and Labrador vs. Other Provinces, 2012

\begin{tabular}{|c|c|c|c|c|c|c|c|c|c|c|}
\hline Region & Hospitals & $\begin{array}{c}\text { Other } \\
\text { Institutions }\end{array}$ & Physicians & $\begin{array}{c}\text { Other } \\
\text { Professionals }\end{array}$ & Drugs & Capital & $\begin{array}{l}\text { Public } \\
\text { Health }\end{array}$ & Admin & $\begin{array}{c}\text { Other } \\
\text { Health } \\
\text { Spending }\end{array}$ & Total \\
\hline & \multicolumn{10}{|c|}{ Per Capita Spending 2012 (in 2014 dollars) } \\
\hline $\mathrm{BC}$ & 1,745 & 218 & 901 & 39 & 227 & 184 & 379 & 46 & 285 & 4,024 \\
\hline $\mathrm{AB}$ & 2,101 & 395 & 952 & 59 & 341 & 217 & 265 & 39 & 178 & 4,546 \\
\hline SK & 1,706 & 618 & 874 & 32 & 308 & 226 & 425 & 47 & 305 & 4,541 \\
\hline $\mathrm{MB}$ & 1,950 & 638 & 832 & 28 & 271 & 234 & 292 & 47 & 363 & 4,654 \\
\hline ON & 1,457 & 405 & 953 & 32 & 343 & 169 & 264 & 32 & 171 & 3,826 \\
\hline QC & 1,409 & 537 & 707 & 29 & 321 & 289 & 117 & 48 & 160 & 3,617 \\
\hline NB & 1,993 & 549 & 813 & 9 & 277 & 267 & 174 & 41 & 274 & 4,399 \\
\hline NS & 1,790 & 681 & 813 & 14 & 300 & 334 & 119 & 105 & 182 & 4,340 \\
\hline $\mathrm{PE}$ & 1,907 & 551 & 694 & 18 & 270 & 566 & 232 & 114 & 214 & 4,566 \\
\hline NL & 2,350 & 781 & 867 & 21 & 299 & 359 & 189 & 72 & 364 & 5,302 \\
\hline CAN & 1,627 & 446 & 876 & 34 & 316 & 222 & 245 & 44 & 203 & 4,013 \\
\hline \multicolumn{11}{|c|}{$10=$ lorwest } \\
\hline $\begin{array}{l}\text { NL's } \\
\text { Rank }\end{array}$ & 1 & 1 & 5 & 7 & 6 & 2 & 7 & 3 & 1 & 1 \\
\hline \multicolumn{11}{|c|}{$\begin{array}{l}\text { Notes: Spending figures from } 2012 \text { have been inflated using CIHI's Government Expenditure Implicit Price Index to their } 2014 \\
\text { values. "Other professionals" include care primarily provided by dental and vision care professionals; "Other institutions" include } \\
\text { nursing homes and residential care facilities; "Public Health" includes expenditures for items such as food and drug safety, health } \\
\text { inspections, health promotion activities, community mental health programs, public health nursing, the prevention of spreading } \\
\text { disease and health promotion. }\end{array}$} \\
\hline \multicolumn{11}{|c|}{ Source: Canadian Institute for Health Information, 2014.} \\
\hline
\end{tabular}




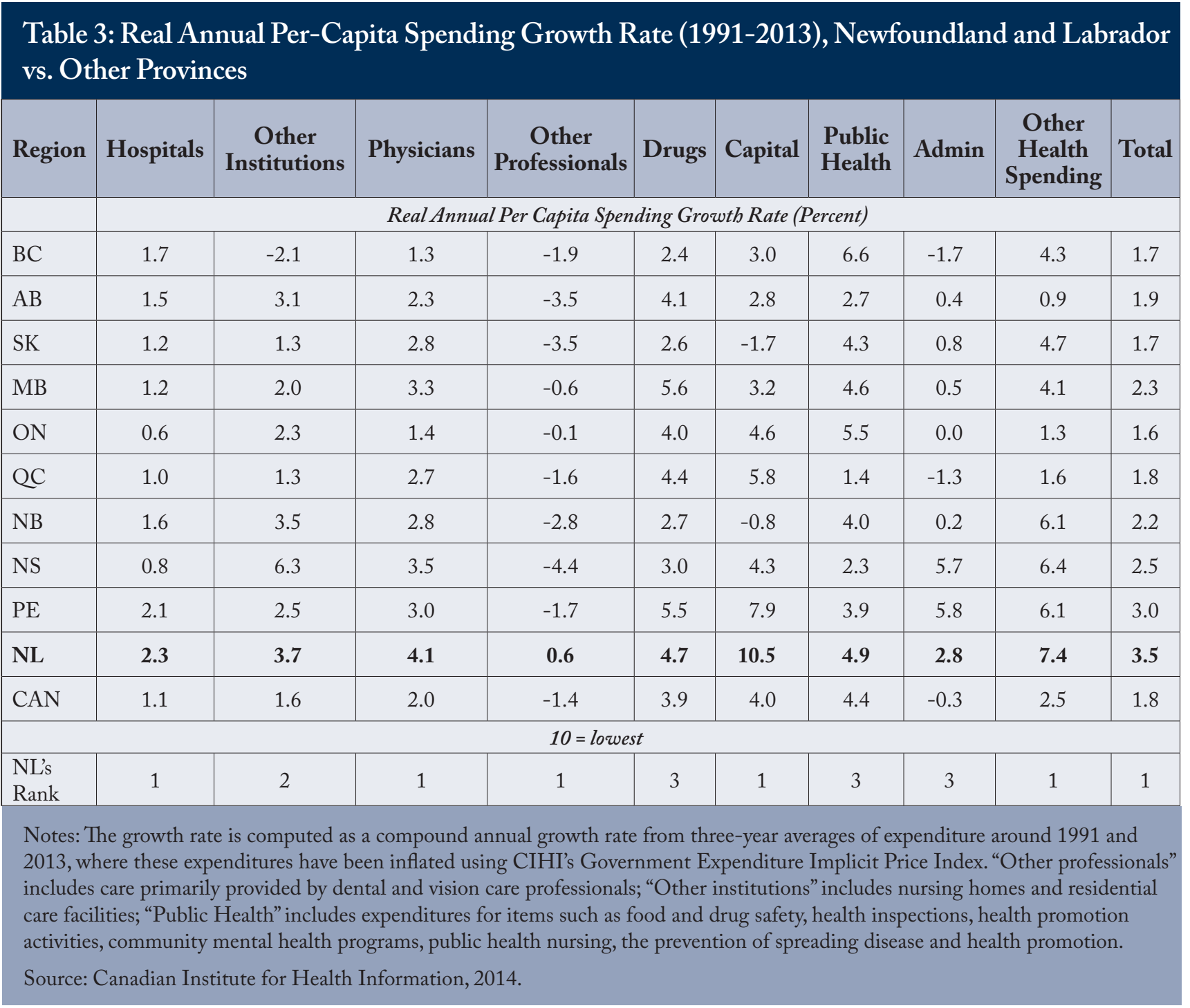

\section{References}

Barer, M.L., R.G. Evans and C. Hertzman. 1995. "Avalanche or Glacier? Health Care and the Demographic Rhetoric." Canadian Journal on Aging 14(2): 193-224.

Brown, Robert, and Uma Suresh. 2004. "Further Analysis of Future Canadian Healthcare Costs.” North American Actuarial Journal 8(2). April.

Blomqvist, Ake and Colin Busby. 2014. Paying for the Boomers: Long-Term Care and Intergenerational Equity. Commentary 415. Toronto: C.D. Howe Institute. September.

Busby, Colin, and William B.P. Robson. 2011. A Social Insurance Model for Pharmacare: Ontario's Options for a More Sustainable, Cost Effective Drug Program. Commentary 326. Toronto: C.D. Howe Institute. April. 
Busby, Colin, and Jonathan Pedde. 2014. Should Public Drug Plans be Based on Age or Income? Commentary 417. Toronto: C.D. Howe Institute. November.

Canadian Institute for Health Information (CIHI). 2014. National Health Expenditure Trends, 1975-2014. Ottawa.

Drummond, Don, and Derek Burleton. 2010. "Charting a Path for Sustainable Healthcare In Ontario: 10 Proposals to Restrain Costs Without Compromising Quality of Care.”TD Economics Special Report. Toronto: TD Bank Financial Group. May.

Emery, J.C. Herbert, David Still and Tom Cottrell. 2012. "Can We Avoid a Sick Fiscal Future? The NonSustainability of Health-Care Spending with an Aging Population.” SPP Research Papers, Vol. 5, No. 31. October.

Evans, Robert G., Kimberlyn M. McGrail, Steven G. Morgan, Morris L. Barer, and Clyde Hertzman. 2001. "Apocalypse No: Population Aging and the Future of Health Care Systems." Canadian Journal on Aging, 20 (suppl. 1).

Felder, Stephan. 2013 “The Impact of Demographic Change on Healthcare Expenditure.” CESifo DICE Report 1/2013: Managing the Healthcare System. Spring. s

Laurin, Alexandre. 2012. "Tuer la poule aux oeufs d'or : Les impacts des hausses d'impôt proposées au Québec.” C.D. Howe Institute E-Brief. 2 October.

Office of the Chief Actuary. 2012. Actuarial Report (11th) on the Old Age Security Program, as at 31 December 2009. Ottawa: Office of the Superintendent of Financial Institutions.

Robson, William. 2002. Saving for Health: Pre-Funding Health Care for an Older Canada. Commentary 170.

Toronto: C.D. Howe Institute. October.

.2007. "Time and Money: The Challenge of Demographic Change and Government

Finances in Canada.” Backgrounder 109. Toronto: C.D. Howe Institute. December.

.2010. “The Glacier Grinds Closer: How Demographics Will Change Canada's Fiscal Landscape.” E-Brief. Toronto: C.D. Howe Institute. January.

Stabile, Mark, and Jacqueline Greenblatt. 2010. "Providing Pharmacare for an Aging Population: Is

Prefunding the Solution?” IRPP Study 2. Montreal. February.

Statistics Canada. 2011. Summary of Public School Indicators for the Provinces and Territories, 2005/06 to 2009/10. Culture, Tourism and the Centre for Education Statistics: Research Papers. Cat no. 81-595MWE2011095. Ottawa: Statistics Canada. November.

This E-Brief is a publication of the C.D. Howe Institute.

Colin Busby is a Senior Policy Analyst at the C.D. Howe Institute.

William B.P. Robson is President and Chief Executive Officer of the C.D. Howe Institute.

Aaron Jacobs is a Research Intern at the C.D. Howe Institute.

This E-Brief is available at www.cdhowe.org.

Permission is granted to reprint this text if the content is not altered and proper attribution is provided. 